\title{
8 Human flourishing and CONFLICT IN AFRICAN HUMAN RIGHTS LAW
}

\section{Niklas Hultin ${ }^{1}$}

\section{INTRODUCTION}

What role can human rights law - specifically human rights law as it is being developed, refined, and innovated in the African context - play in the protection and promotion of human flourishing? At first glance, the answer might seem obvious; human rights are seen as an unequivocal good and therefore they are undeniably helpful in promoting flourishing. But this answer is insufficiently specific, in that it does not take into account the legal issues, both procedural and substantive, that pertain to flourishing on the African continent, nor does it operate with a clear understanding of what flourishing actually is. Put another way, we should ask how human rights institutions help in promoting and protecting flourishing and how these institutions can be used for that purpose. This chapter is an attempt to give some specificity to this question, focusing in particular on the African human rights system. It is my central contention that this system - consisting of the African Commission on Human and Peoples' Rights (ACHPR), established by the African Charter on Human and Peoples' Rights (African Charter for short), and the African Court on Human and Peoples' Rights (ACtHPR), established by a subsequent protocol to the African Charter - has been at the forefront of protecting human flourishing in times of conflict and in times of peace and has in substantial ways moved past the contributions of the other regional systems, as well as the United Nations. ${ }^{2}$ In and of itself, this point is important, as international legal discussions tend to dismiss African developments as imperfect implementations of universal standards, whose Western provenance is often taken for granted. ${ }^{3}$ Furthermore, while there has been a great deal of criticism, much justified, of the efficacy and impact of the African human rights system, it is nonetheless the case that its

1 Assistant Professor, Global Affairs Program, George Mason University.

2 The term "African human rights system" is a commonly used shorthand for the ACHPR and ACtHPR, in contradistinction to their European or Inter-American counterparts (the European human rights system and the Inter-American human rights system, respectively). See, for example, IJRC. 2007. Advocacy before the African Human Rights System: A Manual for Attorneys and Advocates. San Francisco, CA: International Justice Resource Center. Non-governmental organisations are sometimes included in discussions of the African human rights systems, as these have both formal and informal roles to play, surpassing the roles they play in the other regional systems. See, generally, Ölz MA. 1996. "Non-Governmental Organizations in Regional Human Rights Systems", Columbia Human Rights Law Review 28:307-374. Herein, the term is used to refer to ACHPR and ACtHPR only.

3 See, for example, Murray R. 2006. “International Human Rights: Neglect of Perspectives form African Institutions", International and Comparative Law Quarterly 55(1):193-204. 
decisions have an important signalling effect to oppressed groups, human rights activists, and states themselves - as shown, for example, by recent developments in Kenya regarding minority rights, which will be discussed herein.

The chapter is divided into two sections following this introduction and a conclusion. In the first section, I will briefly discuss human flourishing as it pertains to the context of human rights law and in relation to conflict. It will be shown that flourishing is best thought of as a series of postulates, one of which being that it is necessarily collective or, rather, that flourishing happens in relations with and to others. In the second section, I will review the contribution of the African human rights system to flourishing, using some of the key decisions coming out of the system in order to show how the African Commission, primarily, and the African Court, secondarily, has approached flourishing, without necessarily using the word. In the final argument, I suggest, the African human rights system has developed, in a manner that is quite distinct from its counterparts in other parts of the world, the importance of flourishing, especially in its collective instantiation, as a key element of human life that merits protection and promotion.

\section{FLOURISHING AS A LEGAL CONCEPT IN TIMES OF PEACE AND WAR}

At the outset, we need to note that there is no concept of flourishing per se in human rights law. There is no codified "right to flourish" in any major treaty or declaration. A few authors, such as Jack Donnelly and Martha Nussbaum, have discussed human rights as a way of achieving flourishing, but here it exists, in a sense, outside the law - or, rather, human rights law is simply a means to the end of flourishing. ${ }^{4}$ Nussbaum's work is especially pertinent here, nonetheless, as she defends an "essentialism of a kind" that accounts in a context-sensitive way for basic human needs and wants. ${ }^{5}$ Nussbaum's defence of the Aristotelian approach to human needs, paves the way for scholars such as Douglas Rasmussen, who argues that we can understand flourishing as consisting of several dimensions: ${ }^{6}$

- First, it is an objective good and not simply a subjective experience; flourishing has the intrinsic quality of being good and it is not simply instrumentally derived. That is, flourishing is not simply a means to an end that is good because the end is good. Flourishing in and of itself is good, irrespective of the end - or, rather, the end is subsumed in it.

4 Donnelly J. 2007. “The Relative Universality of Human Rights”, Human Rights Quarterly 29(2):281-306; Nussbaum M. 2007. "Human Rights and Human Capabilities", Harvard Human Rights Journal 20:21-24.

5 Nussbaum M. 1992. "Human Functioning and Social Justice: In Defense of Aristotelian Essentialism", Political Theory 20(2):202-246, 205.

6 Rasmussen DB. 1999. "Human Flourishing and the Appeal to Human Nature", Social Philosophy and Policy 16(1):1-43. See also Ryan RM et al. 2013. "What Humans Need: Flourishing in Aristotelian Philosophy and Self-Determination Theory", in Waterman AS (ed). The Best Within Us: Positive Psychology Perspectives on Eudaimonia. Washington, DC: American Psychological Association, 57-75. 
- Second, it is to be found in action - to flourish one must be able to do certain things. It is not, once again, simply a means to an end but an end in itself that encompasses other subsidiary goals. But this also means that flourishing is not simply, to put it prosaically, a state of mind, but rather exists in the ability to do certain things.

- Third, flourishing is individuated and inextricably linked to the particular circumstances of people's lives, though it is not simply the expression of subjective whims. As Rasmussen puts it, the "generic goods and virtues of human flourishing are not like Recommended Daily Allowances for vitamins and minerals" but, rather, the allocation and weighting of these to achieve flourishing is individuated. ${ }^{7}$

- Fourth, flourishing assumes a measure of agency and self-direction - flourishing cannot, in a sense, be imposed. ${ }^{8}$ Indeed, given that flourishing is not external to the human agent, self-direction is not simply a precondition of flourishing, but an aspect of flourishing itself.

- Fifth, human flourishing is social and achieved in relation to others, through binds of friendship, love, and community, though it does not presume or prescribe a specific community. In other words, flourishing might be enacted in a solitary fashion at any given moment, but it presumes the ability to engage in flourishing with others.

The above list is undoubtedly a simplification, but it nonetheless suggests postulates that in various ways correspond to assertions of human rights generally and the African human rights system particularly. These assertions include ideas of consent and participation, which are important to the right to development and the right to participate in the political affairs of one's country, rights such as freedom of religion and expression, and the notion that some human rights cannot be fulfilled outside of a collective. As we will see below, it is this final point, in particular, to which the African human rights system has something to add.

It is also evident that there is a kinship between flourishing as sketched out above and the capabilities approach to human rights and development associated with scholars like Amartya Sen and the aforementioned Martha Nussbaum. ${ }^{9}$ Very briefly put, one of the hallmarks of this approach, in line with flourishing, is that processual and substantive freedoms are both intrinsically important and interdependent with each other or, as Sen puts it, "capabilities and the opportunity aspect of freedom ... have to be supplemented by considerations of fair processes

7 Rasmussen, "Human Flourishing and the Appeal to Human Nature", 6.

8 This point is well captured by Leopold's discussion of Karl Marx's ambivalence towards the institutions of flourishing. That is, Marx expressed a dismay over the shortcomings of bureaucratic organisations when it comes to promoting flourishing, suggesting that despite avowals of working for the common good, the administrative apparatus is the preserve of the dominant class. See Leopold D. 2007. The Young Karl Marx: German Philosophy, Modern Politics, and Human Flourishing. New York, NY: Cambridge University Press, 249.

9 See Sen A. 2005. "Human Rights and Capabilities", Journal of Human Development 6(2):151-166; Nussbaum, "Human Functioning and Social Justice". 
and the lack of violation of peoples' rights to invoke and utilize them." ${ }^{10}$ Indeed scholars such as Michael Hannis have developed the capabilities approach further, linking it, in his case to "intergenerational justice of capabilities for flourishing". ${ }^{11}$ This formulation highlights (a) the processual aspect of flourishing, its demands on processual equity and transparency, for instance; (b) flourishing's contingency and flexibility; and (c) adds that flourishing is also about future generations (to flourish now, the next generation must be able to flourish, and vice versa). In other words, social reproduction is essential, which arguably underscores the collective aspects of flourishing. ${ }^{12}$

One other aspect of flourishing is its connection to suffering and hardship. This connection is particularly important in terms of understanding flourishing in relation to conflict and, as the title of this chapter suggests, of particular interest is the African human rights system's contribution to the protection and promotion of flourishing within situations of conflict and unrest. Taken at face value, flourishing might seem to depend on peace. This take would seem to be consistent with, for example, that of Johan Galtung, who is widely considered one of the founders of peace and conflict studies, influential formulation of structural violence. However, to Galtung, violence is something that prevents other people from fulfilling their potential; it is thus not reducible to physical, direct, violence but may also be, for example, indirect and non-physical. ${ }^{13}$ From this point of view, there really is not a strict peace/conflict binary as such, but, rather, a continuum of circumstances that, in different ways, impact the ability of a group or person to flourish. This is not to say that conflict, abuse or violence in and of itself irrevocably stops flourishing in its tracks - in fact, some perspectives on flourishing highlight that suffering can in and of itself lead to flourishing, for example, through a spiritual awakening. ${ }^{14}$

In this vein, it bears noting that the African human rights system does not really distinguish between peace and conflict. That is, a state party has the same obligations to its citizens whether there is a state of war, political unrest, or not. Unlike the European human rights system, for example, the African Charter on Human and Peoples Rights does not permit derogations - at least in principle, a state cannot cite an emergency such as a riot or public health emergency to suspend temporarily

10 Sen, "Human Rights and Capabilities", 157.

11 Hannis M. 2015. Freedom and Environment: Autonomy, Human Flourishing and the Political Philosophy of Sustainability. New York: Routledge, 3.

12 The underlying assumption here is that we are talking about flourishing in terms of beliefs, norms, aesthetics, etc. or, in short, culture. Without going into detail as to what "culture" is, I take it as axiomatic that culture implies a set of shared and socially-transmitted values that are taught and learned across generations. See, for example, Urban G. 2000. A Discourse-Centered Approach to Culture: Native South American Myths and Rituals. Second Edition. Tucson, AZ: Hats Off Books.

13 Galtung J. 1969. “Violence, Peace, and Peace Research”, Journal of Peace Research 6(3):168.

14 Hall EL, Langer R and McMartin J. 2010. "The Role of Suffering in Human Flourishing: Contributions from Positive Psychology, Theology, and Philosophy", Journal of Psychology and Theology 38(2):111-121. 
certain rights. So, for example, the African Charter contains several provisions similar to those find in other human rights documents governing, for example, equality before the law (Article 3) and freedom of religion (Article 8), and, strictly speaking, these must be respected at all times, no matter what political or security circumstances abide in the country concerned. ${ }^{15}$ (I am leaving aside the issues of "clawback clauses" ${ }^{16}$ ) It is, of course, the case that African countries are bound by a whole range of human rights and humanitarian standards, whose scope is not restricted to Africa. African countries have overwhelmingly signed on to the key parts of the Law of Armed Conflict - the Geneva Conventions and its Additional Protocols (including Additional Protocol II, which extends the conventions to non-international armed conflicts in certain key respect), along with various treaties banning certain weapons. The Law of Armed Conflict includes provisions relevant to human flourishing, most notably the prohibition on attacking places of worship and sites of cultural heritage. ${ }^{17}$ These have largely developed without significant African input, with the partial exception of the related areas of refugees and small arms control. ${ }^{18}$

In short, to the question of what the African human rights system has to contribute in terms of protecting flourishing at times of conflict, the answer must in part, somewhat counterintuitively perhaps, be that the existence of conflict does not really matter. That is, in a narrowly doctrinarian sense, an African country has the same obligations under the African Charter whether it is at war, at peace, or whether there are riots and other disturbances. There simply is no mechanism in the Charter for, say, Nigeria, to say something along the lines of "we will temporarily restrict freedom of expression due to the Boko Haram conflict" ${ }^{19}$ Instead, we need to pose the more general question of what the African human rights system adds to flourishing: what is different from the other regional human rights systems,

15 See discussion in Umozurike UO. 1983. “The African Charter on Human and Peoples' Rights", American Journal of International Law 77(4):902-912.

Clawback clauses are clauses in human rights articles that undercut - or "claw back" - the point of the article. For example, Article 9(2) of the African Charter reads, in its entirety: "Every individual shall have the right to express and disseminate his opinions within the law." The problem with this formulation is that the phrase "within the law" can severely undercut freedom of expression if the duly adopted laws are excessively restrictive. See, for example, Singh S. 2009. "The Impact of Clawback Clauses on Human and Peoples' Rights in Africa", African Security Studies 18(4):95-104. On the difference between clawback clauses and derogations, see Higgins R. 1977. "Derogations Under Human Rights Treaties", British Yearbook of International Law 48(1):281-319.

17 See Becerril ML. 2012. "The Meaning and Protection of 'Cultural Objects and Places of Worship' Under the 1977 Additional Protocols", Netherlands International Law Review 59(3):455-472.

18 Waschefort G. 2016. "Africa and International Humanitarian Law: The More Things Change, the More They Stay the Same", International Review of the Red Cross 98(902):593-624.

19 The absence of such a mechanism does not, of course, prevent an African country from restricting rights citing such circumstances, but such a restriction would be inconsistent with the African charter as written. 
as well as international treaties? What can we learn about human rights and the protection of flourishing from the African human rights system? Put this way, we can also largely dispense with a discussion of the rights enumerated in the African Charter that can be found elsewhere. For example, Article 8 of the African Charter guarantees freedom of religion and it is generally similar to equivalent rights elsewhere (There are of course differences in case law interpretation, but these are beyond the scope of this chapter.) But if we disregard the similarities, with what are we left in terms of flourishing? The answer to this question lurks in the African Commission on Human and Peoples' Rights very name, that is to say, in the inclusion of "peoples". The key differentiator between the African human rights system and other human rights systems is the very deliberate and explicit focus on collective rights. As will be developed in the following section, this focus has both a procedural and a substantive dimension.

\section{THE AFRICAN HUMAN RIGHTS SYSTEM AND COLLECTIVE FLOURISHING}

Peoples' rights are put forth in a series of articles in the African Charter on Human and Peoples' Rights in ways that do not really have an equivalent in other non-African treaties. ${ }^{20}$ These rights are to be found in Articles 19 through 24 of the African Charter. They are often discussed as collective rights, solidarity rights, or as third generation rights, assuming that civil and political rights are the first generation and socio-economic rights the second generation.

- Article 19 asserts the equality of all people.

- Article 20 asserts that "all people shall have the right to existence".

- Article 21 asserts that people have the right to their natural resources.

- Article 22 asserts that peoples have the right to their own cultural development and a right to development.

- Article 23 asserts that all peoples have the right to "national and international peace and security".

- Article 24, finally, asserts that all people have a right to a "satisfactory environment".

The existence of these rights is often highlighted as evidence that the African human rights system, from its inception, sought to encode a slightly different understanding of human rights than what abides in the European and Inter-American systems, as well as at the UN level. ${ }^{21}$

20 African [Banjul] Charter on Human and Peoples' Rights, adopted June 27, 1981, OAU Doc. CAB/LEG/67/3 rev. 5, 21 I.L.M. 58 (1982), entered into force Oct. 21, 1986. Online at: http://www1.umn.edu/humanrts/instree/z1afchar.htm

21 Kiwanuka RN. 1988. "The Meaning of 'People' in the African Charter on Human and Peoples' Rights", American Journal of International Law (82(1):80-101; Murray R. 2000. The African Commission on Human and Peoples' Rights and International Law. Oxford, UK: Hart Publishing. 
The extent and scope of these rights critically depends on what we mean by "peoples". If, as suggested above, flourishing is necessarily collective, then it makes sense to locate the distinct African contribution to the nexus of human rights and flourishing in these collective rights. But first, we must have some understanding of what is meant by "people" in these rights. Are we talking about people as in "the citizens of a country", such as Nigerians, Senegalese, Ethiopians and forth? Are we talking about "people" as in "humankind", or maybe people living under colonial domination, which would essentially make these paragraphs not applicable to most of African today? Or, are we talking about an ethnic or religious group? ${ }^{22}$ Unsurprisingly, there is a relatively large scholarship on precisely this question, and it has to be said that the African Commission's jurisprudence on this point is still developing. ${ }^{23}$ However, it is increasingly clear, as will be developed below, that the meaning of "people" is a sub-national group such as an ethnic group or indigenous people, the two being not necessarily the same.

It is true that at times the African Commission has treated "people" as equivalent to the citizens of a country. In cases concerning Article 13 (the right to participate in government) and Article 20 (the right to self-determination), the African Commission has held that a people must be able to determine its own "political status", but has done so in a manner that makes it clear that people here means all citizens of a country. ${ }^{24}$ But to complicate matters further, in two relatively early cases, the African Commission suggested that sub-national groups could also be considered a "people". In a communication brought against the Democratic Republic of Congo (then Zaire), the Commission referred to "the people of Katanga", and in a communication brought against Nigeria, the Commission implied that the Ogoni are a people, as understood in the African Charter, by virtue of the fact that Nigeria violated their rights under Article 21 (a people's right to dispose of its natural resources) and 24 (a people's right to a satisfactory environment). ${ }^{25}$

In a subsequent case, 266/03 Kevin Mgwanga Gunme et al. v Cameroon, the Commission developed this point about people further. Cameroon argued that the Southern Cameroonians, the applicants, did not have the rights enumerated in Articles 19 through 24, because they are not a people. Cameroon argued that there is no "ethnoanthropological argument" in favour of classifying Southern Cameroonians as

22 See Kiwanuka, “The Meaning of 'People' in the African Charter on Human and Peoples' Rights", for a breakdown of these different possibilities.

23 A fact recognised by the African Commission. See 279/03-296/05 Sudan Human Rights Organisation \& Centre on Housing Rights and Evictions (COHRE) v Sudan, para 220.

24 102/93 Constitutional Rights Project and Civil Liberties Organisation v Nigeria; 147/95 and 149/96 Sir Dawda K. Jawara v The Gambia.

25 75/82 Katangese Peoples' Congress $v$ Zaire; 155/96 The Social and Economic Rights Action Center (SERAC) and the Center for Economic and Social Righs (CESR) $v$ Nigeria. See also discussion of these cases in Nwobike JC. 2005. "The African Commission on Human and Peoples' Rights and the Demystification of Second and Third Generation Rights Under the African Charter: Social and Economic Rights Action Center (SERAC) and the Center for Economic and Social Rights (CESR) v Nigeria", African Journal of Legal Studies 1(2):129-146. 
a people. The Commission rejected this claim and found that Southern Cameroonians are in fact a people, because they share "a common history, linguistic tradition, territorial connection, and political outlook ... [and also] identify themselves as a people with a separate and distinct identity. Identity is an innate characteristic within a people. It is up to other external people to recognise such existence, but not to deny $\mathrm{it}^{\prime \prime}{ }^{26}$

What these cases suggest is, firstly, that "people" under the African Charter - that is the entities that are entitled to the rights enumerated in Articles 19 through 24 - are sub-state groupings and not simply the people of a country. This point is important on a practical level, given the multi-ethnic and multi-denominational composition of all African countries and the fact that so much conflict on the African continent, as elsewhere, falls along these fault lines. Secondly, that selfidentification is fundamental and that the "group-ness" of a group cannot be denied by a government, assuming, presumably, that the would-be group has some of the attributes enumerated in the Kevin Mgwanga Gunme et al. case (see above). This is not to say that any group's assertion of deprivation along any of the dimensions of Articles 19 through 24 will inevitably lead to a finding of a violation. In 328/06 Front for the Liberation of the State of Cabinda $v$ Angola, the Commission held that in order for a violation to be found, a group has to be treated worse than other groups:

[D]istinct and identifiable groups of "peoples" and communities exist within the State Parties to the African Charter and each set of "peoples" and communities is entitled to enjoy internal legal equality vis-a-vis other "peoples" and communities within the same state. The Commission notes that a claim of unequal treatment in violation of Article 19 of the Charter requires evidence that a given group or set of peoples who is in a position similar to another group or set of people has been or is being treated differently or that a given group or set of peoples who is in a position different to another group or set of people is treated similarly such that the "peoples" complaining suffer unfair and unjustifiable disadvantage that amounts to discrimination. ${ }^{27}$

In other words, the Commission treated the existence of multiple sub-national "peoples" as self-evident, asserted that the key issue the point of view of Article 19 is whether one such people is treated worse than any other people.

The above discussion largely focuses on who or what kind of entities can claim violations under Article 19 through 24. We can fruitfully think of this is a procedural aspect of flourishing in the African human rights system, namely, in delineating under what circumstances a claim to flourishing violation might occur, above and beyond what could be argued in other systems. The substantive issues or situations that may give rise to such violations are in some ways less developed by the African Commission. The vast majority of cases it has heard concern other provisions, but the above cases alongside a few others give a sense of the contours of these rights.

26 266/03 Kevin Mgwanga Gunme et al. v Cameroon, para 178.

27 328/06 Front for the Liberation of the State of Cabinda $v$ Angola, para 114. 
In the aforementioned case against Nigeria, for example, the African Commission held that the Nigerian government's failure to take any environmental or health impact before oil extraction constituted a violation of Article $24 .^{28}$

In another case, 227/99 Democratic Republic of the Congo $v$ Burundi, Rwanda, and Uganda, the African Commission found that the "indiscriminate dumping of and/or mass burial of victims" constituted a violation of the right to cultural development under Article 22 of the Charter as well as "an affront on the noble virtues of the African historical tradition and values enunciated in the preamble to the African Charter". ${ }^{29}$ The reference to the African historical tradition is a rhetorical flourish that obscures the fact that ill treatment of war dead, even the bodies of enemies, is widely held to be an affront to human dignity-human rights law scholar Christopher McCrudden, for example, links this issue, via Grotius, to the pervasiveness of "dignity" in human rights discourse. ${ }^{30}$ Nonetheless, if read in conjunction with the other cases referenced above and with the understanding of flourishing as developed in the first section, we can get more of a sense of the kinds of substantive issues that the African Commission is well positioned to protect. These would indubitably include cultural practices essential to cultural identity, such as burial rites, and the environment, political as well as physical, in which those can be safely carried out.

While the focus above has been on the violation of a collective's collective rights the clunky wording is deliberate - it is also the case that a denial of an individual's right can lead to a violation of a people's rights. In a communication brought against Côte d'Ivoire, the Commission considered an alleged violation of the Article 22 right to economic, social, and cultural development. In that case, the applicant did not allege violations of any other people's rights. Here, the Commission suggested that Côte d'Ivoire's failure to recognise members of the Dioula ethnic group as citizens negatively impacted an individual's "life plan" which, in turn, led to a "serious violation of the right to development under the provisions of Article 22". The Commission's reasoning was that Côte d'Ivoire's failure to recognise the Dioulas as citizens "hinder[ed] every possibility with them to decide with other Ivorians choices relating to the destiny of the Ivorian nation". ${ }^{31}$

These different aspects of the protection of flourishing, which I have somewhat loosely referred to as the procedural and substantive ones, have been brought together in two cases brought against Kenya concerning indigenous peoples - one of which has also been addressed by the African Court. In 276/03 Centre for Minority Rights Development (Kenya) and Minority Rights Group (on behalf of Endorois Welfare Council) $v$ Kenya, the African Commission examined the eviction of the Endorois

28 155/96 Social and Economic Rights Action Center (SERAC) and the Center for Economic and Social Rights (CESR) v Nigeria, para 53-54.

29 227/99 Democratic Republic of the Congo v Burundi, Rwanda, and Uganda, para 87.

30 McCrudden C. 2008. "Human Dignity and Judicial Interpretation of Human Rights", European Journal of International Law 19(4):655-724.

31 318/06 Open Society Justice Initiative v Côte d'Ivoire, para 185-186. 
ethnic group by the Kenyan government, so that the latter could establish a game reserve. The Commission concluded that the Endorois did meet the criteria of "people"; whereas Kenya had alleged that they did not. The Commission argued: that: "[It] is satisfied that the Endorois are a 'people', a status that entitles them to benefit from provisions of the African Charter that protect collective rights. The African Commission is of the view that the alleged violations of the African Charter are those that go to the heart of indigenous rights - the right to preserve one's identity through identification with ancestral lands." 32

Furthermore, the African Commission argued that even though the establishment of a game reserve could be considered a "public good", any such initiative attempted by a state must take the least restrictive approach possible. Here, the Commission noted, the Endorois were actually willing to work with the Kenyan government, but the latter refused to do so. This led to the Endorois' rights being rendered illusory. ${ }^{33}$ Somewhat similarly, the Commission sided with the Endorois claim that the creation of a game reserve would pose significant harm to their culture. On this point, the Commission noted that the "universal appeal of great culture lies in its particulars and that imposing burdensome laws or rules on culture undermines its enduring aspects". ${ }^{34}$ In addition, the African Commission also asserted that the right to development (Article 22) has a procedural and substantive dimension. The procedural dimension means that there can be no pressure or coercion on the Endorois to "buy into" a Kenyan development plan. ${ }^{35}$

On the latter point, the African Commission based themselves on an earlier case concerning the Ogiek people of Kenya. This situation found its way to the African Court when the African Commission brought a case against Kenya because of the latter's refusal to follow a provisional order issued by the Commission. The circumstances in this case were broadly similar to the Endorois case. According to the court itself, the central question was whether the Ogiek are an indigenous people. The applicants argued that the Ogiek are an indigenous people for two reasons: (a) they have lived in the Mau Forest "for generations since time immemorial" and (b) "their way of life and survival as a hunter-gatherer community is inextricably linked to the forest which is their ancestral land." 36 The government of Kenya responded to this claim by saying that the Ogiek (a) "are not a distinct ethnic group but rather a mixture of various ethnic communities" and (b) "the Ogieks of today ... [have] adapted themselves to modern life and are currently like all other Kenyans." ${ }^{37}$

32 Centre for Minority Rights Development (Kenya) and Minority Rights Group (on behalf of Endorois Welfare Council) v Kenya, para 162.

33 Centre for Minority Rights Development (Kenya), para 215.

34 Centre for Minority Rights Development (Kenya), para 249.

35 Centre for Minority Rights Development (Kenya), para 128.

36 006/2012 African Commission on Human and Peoples' Rights v Kenya, para 103.

37 006/2012 African Commission on Human and Peoples' Rights, para 4. 
The African Court found that the Ogiek met the criteria of indigenous people as outlined above. In deliberating the alleged violation of Article 21, the African Court re-visited the meaning of "people" in the Charter and affirmed that "people" "can be extended to include sub-state ethnic groups". ${ }^{38}$ More importantly, the African Commission asserted that the African Charter's Article 22 must be interpreted in light of the UN Declaration on the Rights of Indigenous People, so that people have the right to be "actively involved in developing and determining health, housing and other economic and social programmes affecting them". ${ }^{39}$ That "actively involved" must be understood in light of a community's right to flourish is underlined by the African Court in a striking paragraph worth quoting extensively:

[T] he protection of the right to culture goes beyond the duty, not to destroy or deliberately weaken minority groups, but requires respect for, and protection of, their cultural heritage essential to the group's identity. In this respect, culture should be construed in its widest sense encompassing the total way of life of a particular group, including the group's languages, symbols such as dressing codes and the manner the group constructs shelters; engaging in certain economic activities; produces items for survival; rituals such as the group's particular way of dealing with problems and practicing spiritual ceremonies; identification and veneration of its own heroes or models and shared values of its members which reflect is distinctive character and personality. ${ }^{40}$

Collectively, these decisions from the African Commission and Court have thus increasingly recognised that members of sub-state groups have the right to chart, in a manner of speaking, their own developmental destiny and to pursue their own values in a manner of their choosing - in other words, to flourish. This right cannot be unduly limited or nullified, by hoary exhortations of national interests or the public good. In addition, the bearers of these rights are collectivities that cannot simply pulled from some pre-existing list of approved ethnic groups or the like.

\section{CONCLUSION}

When considering flourishing in the context of human rights, one is struck by the concepts' absence in human rights discussions and legal texts. Perhaps this is not all that surprising given the concepts' roots in theology and psychology, and it is certainly the case that there are concepts and notions within the human rights literature, such as "dignity" that speak to broadly similar concerns. This chapter has taken a slightly different tack, however, by starting with flourishing and exploring how the African human rights system can protect and promote flourishing through

\section{6/2012 African Commission on Human and Peoples' Rights, para 199.}

006/2012 African Commission on Human and Peoples' Rights, para 209-210. See United Nations Declaration on the Rights of Indigenous Peoples, G.A. res. 61/295, U.N. Doc A/RES/61/295 (2007).

006/2012 African Commission on Human and Peoples' Rights, para 179. 
its existing jurisprudence. The focus has been on the part of the African human rights system that does not have a direct analog in other systems, namely that of peoples' rights, with the assumption that this focus would most clearly delineate the African human rights system's distinct contribution.

From this point of view, it is clear that the way the African human rights system approaches peoples' rights gives heft to the idea that not only are human rights worth protecting in the interest of flourishing, but that the institutions of human rights law are a possible avenue for the protection of flourishing. Furthermore, the absence of derogations in the African system distinguishes it from other human rights systems on this point. Here, in the African context, the applicability of human rights to flourishing is independent of whether the country is in a state of war, a state of peace, or some murky middle ground. In its growing insistence on a set of collective rights focusing on culture and development, the African human rights system has carved out not simply a distinctive jurisprudence, but a clear statement on the centrality of the kind of self-directed, collective, and contingent good that is flourishing. 